\title{
Resistance of Zymoseptoria tritici to azoxystrobin and epoxiconazole in the lower North Island of New Zealand
}

\author{
T.M. Stewart ${ }^{1}$, A.J. Perry ${ }^{1}$ and M.J. Evans ${ }^{2}$ \\ ${ }^{1}$ Massey University, PO Box 11-222, Palmerston North, New Zealand \\ ${ }^{2}$ PGG Wrightson Grain, Private Bag 1002, Feilding, New Zealand \\ Corresponding author: t.stewart@massey.ac.nz
}

\begin{abstract}
In response to a suspected fungicide resistance problem in the spring of 2013, 23 isolates of Zymoseptoria tritici (also known as Mycosphaerella graminicola) were collected from wheat fields showing symptoms of speckled leaf blotch around the lower North Island. $\mathrm{EC}_{50}$ values for the collected isolates and three sensitive isolates against rates of azoxystrobin, epoxiconazole and isopyrazam were determined by growth in microplates as measured by light absorbance. Furthermore, greenhouse inoculations on fungicide-sprayed plants were conducted with selected isolates. Resistance to azoxystrobin appears widespread, as does reduced sensitivity to epoxiconazole. Most growers supplying the samples were using epoxiconazole as their standard cereal fungicide but at lower than label rates. A combination of conducive weather, low fungicide rates, resistance to azoxystrobin and reduced sensitivity to epoxiconazole is likely to have contributed to the disease epidemic.
\end{abstract}

Keywords speckled leaf blotch of wheat, fungicide resistance, Quinine outside Inhibitor, demethylation Inhibitor, Succinate dehydrogenase Inhibitors, reduced sprays.

\section{INTRODUCTION}

Speckled leaf blotch caused by Zymoseptoria tritici (Desm.) Quaedvlieg \& Crous 2011 (Quaedvlieg et al. 2011) (also known as Mycosphaerella graminicola and Septoria tritici) is a major disease of wheat (Triticum aestivum) globally and in New Zealand. The pathogen is of most significance in autumn-sown wheat crops where infection of the flag, second and third leaf can cause significant losses (Shaw \& Royle 1993; Eyal 1999; Jørgensen et al. 2014). In New Zealand, well-timed fungicide applications play a large role in managing the disease. However, speckled leaf blotch is not the only disease under consideration when applying fungicides to an autumn-sown wheat crop. Major pathogens like stripe rust (Puccinia striiformis f.sp. tritici), leaf rust (Puccinia triticana) and powdery mildew (Blumeria graminis f.sp. tritici) are also considerations. To control all foliar diseases, growers are recommended to monitor the crop and, depending on cultivar susceptibility, disease presence and/or rain or irrigation status, apply fungicides at the following times: GS31-32 ( $1^{\text {st }}-2$ nd node on main stem); GS39 (flag leaf emergence on main stem); GS59-61 (ear emergence - start of flowering) and GS69-72 (post-flowering). An optional application before these sprays at GS30 (end of tillering/start of stem elongation) is recommended if stripe rust is evident (Foundation for Arable Research 2012). This control regime means two to four fungicide applications are typically made over this period. 
There are three dominant chemical groups in commonly used cereal fungicides: the QoI fungicides (also known as the strobilurins), the DMIs (the demethylation inhibitors, also known as the triazole or azole group) and the recently introduced succinate dehydrogenase inhibitors or SDHIs.

Zymoseptoria tritici resistance to all three groups has been noted in laboratory or field studies (Skinner et al. 1998; Fraaije et al. 2005; Cools et al. 2005). Field resistance to QoIs is conferred by a single point mutation in the cytochrome $b$ gene, which causes a G143a substitution. This prevents the fungicide from binding to the Qo site restoring the ability of the fungus carry out microbial respiration (Fraaije et al. 2005). QoI-resistant isolates of the pathogen are now widespread in Europe (Torriani et al. 2009). While DMI fungicides, like the QoIs, have a single biochemical target site, the mechanism of resistance to the DMIs is polygenic, consisting of three primary mechanisms that can combine to determine resistance levels. These mechanisms are mutations in the target-encoding CYP51 gene resulting in decreased affinity of the protein for inhibitors, over-expression of the target CYP51 gene and increased efflux caused by the over-expression of genes encoding membrane transporters. Resistance expression and crossresistance within the DMI group is dependent on which combinations of mechanisms are present in any given population (Cools \& Fraaije 2013). Consequently, DMI resistance development has been more gradual than with the QoIs although reports of resistance to commonly used DMI fungicides are increasing (Cools 2008; Cools et al. 2011; Stammler \& Semar 2011). Regarding the SDHI group, isolates of $Z$. tritici have been found with the necessary mutations in genes encoding for the mitochondrial succinate dehydrogenase $(\mathrm{SDH})$ enzyme to confer resistance. Although the frequency of these mutations for SDHI resistance appears too low to affect field performance, there is a fear that incremental mutations may lead to cross-resistance and eventual loss of control (Sierotzki 2013).
Sensitivity to QoI and DMI fungicides in Canterbury wheat crops were investigated in 2004-2005 and again in 2008 but no resistance was evident (Foundation for Arable Research 2013). However, work during the 2013-2014 seasons showed reduced sensitivities to both of these fungicide groups (R. Craigie, Foundation for Arable Research, personal communication).

Cereals are popular cash crops in the lower North Island. While barley tends to be more favoured, in 2012 there was approximately 2313 hectares of wheat grown producing a total of 14278 tonnes (Statistics New Zealand 2012), which represents $2.9 \%$ of the national wheat crop. The region has seen a shift in the last 10 years from spring-sown wheat to autumnsown wheat. It is estimated that $70 \%$ of the lower North Island wheat crop is now planted in the autumn.

In the spring of 2013, specked leaf blotch of wheat was a serious problem in a number of fields in Manawatu/Rangitikei. One factor may have been the development of resistance to the fungicide groups mentioned above. To investigate this, a number of isolates from several areas in the lower North Island were collected and their resistance status determined by a microplate assay. Fungicide pot trials on selected isolates were also carried out.

\section{MATERIALS AND METHODS Sample collection}

Leaves from wheat plants showing symptoms of speckled leaf blotch were collected from autumn-sown wheat fields in the lower North Island between 16 October and 5 December 2013. The growers were all clients of PGG Wrightson Grain, which services $60-70 \%$ of wheat producers in the region. At the time of collection, the fungicides applied to the crop to date were recorded.

Not all the leaf samples received led to successful Z. tritici isolations. Some samples had remained moist for too long and had been overrun by saprophytes while others were showing symptoms but had few pycnidia. Of the 29 samples submitted, isolates were successfully recovered from 23 . 
Isolates labelled 001 to $012,018,021,023$ and 023 were from the Manawatu/Rangitikei area; 013 to 017,022 and 025 were from fields around the Ruapehu area; 026 to 029 were from Wairarapa and 019 to 020 from Central Hawke's Bay.

Along with isolates collected from lower North Island fields, three isolates with known sensitivity to QoI and DMI fungicides were provided by Plant \& Food Research.

\section{Isolation}

To obtain isolates from plant tissue, a cirrus originating from a single pycnidium from a leaf sample held in high humidity for $24 \mathrm{~h}$ was transferred to a drop of sterile water then streaked onto yeast malt agar (YMA) plates. This was then incubated in the dark at $15^{\circ} \mathrm{C}$. After colonies had formed, presumably originating from a single spore, a single colony was chosen and streaked onto YMA slants.

\section{Fungicides}

Three common cereal fungicides representing the main fungicide groups were included in the assays. These were the QoI azoxystrobin (Amistar ${ }^{\circledR}$ SC), the DMI epoxiconazole (Opus ${ }^{\circledR}$ ) and the SDHI isopyrazam (Seguris Flexi ${ }^{\circledR}$ ). Ideally technical material is best for the assays but this could not be obtained in the time available. Consequently, the tests were conducted with commercial formulations, with the exception of azoxystrobin which was GLP grade formulation. The use of the formulated product appears routine in commercial testing elsewhere in the world and has found to give similar results to technical grade (Gerd Stammler, BSAF, Germany, personal communication).

\section{Assay}

An assay was used to determine the $\mathrm{EC}_{50}$ of each isolate for each fungicide. The $\mathrm{EC}_{50}$ is the concentration at which $50 \%$ of the in vitro fungal growth is inhibited. The assay followed the method of Siah et al. (2010) for QoI testing of $Z$. tritici, with some modifications. It was similar to assay methods published by the Fungicide Resistance Action Committee (FRAC) for all three fungicide groups. Assays were conducted using 96-well flat bottomed microplates. Each well contained $150 \mu \mathrm{l}$ of concentrated liquid glucose peptone growth media amended with fungicides at varying concentrations. Into each well was added a $50 \mu \mathrm{l}$ spore suspension giving a final concentration of $2 \times 10^{5}$ spores/litre. The media ingredients in the final $200 \mu \mathrm{l}$ were $14.3 \mathrm{~g} /$ litre dextrose, $7.1 \mathrm{~g} /$ litre bacto-peptone and $1.4 \mathrm{~g} /$ litre yeast extract.

Fungicide concentrations tested were as follows: azoxystrobin $(0.001,0.01,0.1,1,10$ and $100 \mathrm{mg} /$ litre), epoxiconazole $(0.003,0.01$, $0.03,0.1,0.3,1$ and $3 \mathrm{mg} /$ litre), isopyrazam (0.003, 0.01, 0.03, 0.1, 0.3, 1 and $3 \mathrm{mg} /$ litre). The azoxystrobin treatments were amended with $100 \mathrm{mg} /$ litre of salicylhydroxamic acid (SHAM) to prevent false positives through the possible utilisation of an alternative respiration system. Isolates capable of this may indicate resistance in vitro but are unlikely to express field resistance (Ziogas et al. 1997; Wood \& Hollomon 2003).

Wells including spores but no fungicide were included as controls and wells with media alone were also included in the assay to give a base value for the absorbance. Each isolate was grown in three plates, one plate for each fungicide. Each treatment (i.e. fungicide concentration) was replicated nine times within a plate while media-alone wells were replicated three times for each treatment.

After preparation the microplates were covered with sterile lids, wrapped in tinfoil and incubated at $18^{\circ} \mathrm{C}$ for 7 days on a shaker at $140 \mathrm{rpm}$. After this period they were read in a microplate reader at an absorbance of $405 \mathrm{~nm}$.

$\mathrm{EC}_{50}$ values were determined by non-linear regression (dose response curve) using least squares as the fitting method. The software packaged use was GraphPad Prism 6 (Hearne Scientific Software).

\section{Pot trials}

In pot trials, full, $75 \%, 50 \%$ and $25 \%$ of recommended field rates of azoxystrobin and epoxiconazole product were assessed for their ability to prevent infection and pathogen development against two isolates of $Z$. tritici tested above. These rates equated to $187.5,140.6$, 
93.8 and $46.9 \mathrm{~g} / \mathrm{ha}$ azoxystrobin and 125, 93.8, 62.5 and $31.3 \mathrm{~g} /$ ha epoxiconazole. Isolate 007 was chosen as it showed resistance to azoxystrobin and showed a higher $\mathrm{EC}_{50}$ than most others to epoxiconazole. Isolate PF 23C2 was sensitive to both fungicides and acted as a baseline.

Wheat plants (cv. Morph) were sown in $10 \times 10 \mathrm{~cm}$ planter bags, one seed per bag and grown in a glasshouse until tillering was well underway. Whole plants were then sprayed with the fungicide treatments (4 plants per treatment) using a handheld pressure sprayer calibrated to deliver 2000 litres/ha. After spraying, the plants were left to dry for $4 \mathrm{~h}$ while the isolate suspensions were prepared.

The isolates were grown on YMA for 7 days. The plates were then flooded with reverseosmosis purified water, then filtered through two layers of cheesecloth into a measuring cylinder. The spore concentration was measured with a haemocytometer and adjusted to $5 \times 10^{6}$ spores/ $\mathrm{ml}$. Plants were inoculated by spraying as for the fungicides. One drop of Tween was added to the suspension to aid coverage.

Inoculated plants were randomly arranged on benches in a glasshouse. The benches containing the plants were covered with frame draped with transparent cloth and covered in plastic. For 3 days an automatic watering system applied a mist in the evening ensuring the plants were completely wet during the night. Watering from that point on was by capillary matting. After 7 days the frame was removed leaving the plants to grow in normal glasshouse conditions. The glasshouse was not climate controlled and temperatures fluctuated between $23^{\circ} \mathrm{C}$ in the middle of the day and $12^{\circ} \mathrm{C}$ at night during the period of incubation and disease development.

After 28 days the plants, which were then just commencing stem elongation, were assessed. The three largest tillers in each pot were selected and the $3^{\text {rd }}$ leaf from the top (two down from the emerging leaf) was scored for the presence of lesions with pycnidia giving a total of 12 leaves scored per treatment. The $3^{\text {rd }}$ leaf was selected as this leaf would have been present when the plants were sprayed, and was not starting to senesce like some of the lower leaves.
Fisher's exact test was used to compare treatments and the chi-square test for trend used to check for a relationship within the fungicide treatments. As above, the package used for analysis was GraphPad Prism 6.

\section{RESULTS}

\section{Fungicide applications and rates}

Table 1 shows the fungicides used in the field corresponding to the sample number (which equates to the isolate number) up to the date the samples were collected. It is important to note that the fungicides listed are those that had been used in the crop up to the date of sampling, sometime between 16 October and 5 December. They are not, therefore, reflective of the whole spray programme. It is possible for example, that by the time the last few diseased leaves were collected on the 5 December, other fungicide applications may have occurred on the fields where earlier diseased leaves had been gathered. However, the data do indicate fungicide choice and rates of early spring fungicide applications amongst the growers whose fields were sampled. DMI fungicides such as epoxiconazole featured prominently. QoI fungicides such as azoxystrobin or pyraclostrobin were used occasionally in mixture with a DMI. All fields were sprayed with rates of epoxiconazole ranging from $40 \%$ to $75 \%$ of the recommended rate for speckled leaf blotch (Anonymous 2013). The QoI applications in mixture were also lower than label rates.

None of the growers had used an SDHI fungicide on the crops in question.

\section{Assays}

$\mathrm{EC}_{50}$ values of isolates from the survey ranged from $>0.31$ to $>100 \mathrm{mg} /$ litre for azoxystrobin + SHAM, 0.06 to $0.96 \mathrm{mg} /$ litre for epoxiconazole and 0.01 to $0.22 \mathrm{mg} /$ litre for isopyrazam (Table $2)$. In contrast, the three reference isolates ranged from 0.01 to $0.02 \mathrm{mg} /$ litre for azoxystrobin, 0.03 to $0.04 \mathrm{mg} /$ litre for epoxiconazole and 0.03 to $0.05 \mathrm{mg} /$ litre for isopyrazam.

All isolates exhibited $\mathrm{EC}_{50}$ values for azoxystrobin greater than $100 \times$ in excess of those for the reference ones, with the exception of isolates 004 and 002, which were 
Table 1 Fungicide applications prior the time of sampling in wheat crops visited between 16 October and 5 December 2013. Sample numbers equate to isolates obtained from leaves. The "+" symbol indicates two or more applications of a fungicide. Where only the rate is given on the right hand side of the "+" symbol the fungicide applied was the one on the left. The "/" symbol separating two fungicides indicate they were applied together in a mixture.

\begin{tabular}{ll}
\hline Samples & Fungicides and rate of each application in g/ha \\
\hline 001 & epoxiconazole, $49.8+75$ \\
002 & epoxiconazole, $50+75+94$ / pyraclostrobin, 100 \\
004 & prothioconazole, 100 \\
005,008 & epoxiconazole, $50+75$ \\
006 & epoxiconazole, $50+75+94$ / pyraclostrobin, 100 \\
007 & epoxiconazole, 50 \\
009 & prothioconazole, $150+$ epoxiconazole, 94 / azoxystrobin, 87.5 \\
$010-011$ & epoxiconazole, $50+62.5$ / pyraclostrobin, 87.5 \\
$003,012,013^{1}-017$, & epoxiconazole, 62.5 \\
$021^{1}, 022,025$ & \\
$018^{1}$ & epoxiconazole, $37.5+62.5+$ tebuconazole, 125 / azoxystrobin, 100 \\
$019^{1}$ & epoxiconazole, $50+94+62.5 /$ azoxystrobin, 75 \\
$020^{1}$ & epoxiconazole, $50+62.5$ / azoxystrobin, 75 \\
023 & epoxiconazole, $62.5+50 /$ azoxystrobin, 250 \\
$024^{1}$ & tebuconazole, $187 /$ epoxiconazole, $75+$ \\
$026-028$ & tebuconazole, 187 / epoxiconazole, 75 / azoxystrobin, 125 \\
& prothioconazole, $150+100$ / fluoxastrobin, $50+$ prothioconazole, $150 /$ \\
\hline
\end{tabular}

${ }^{1}$ Unable to isolate Zymoseptoria tritici from infected leaves.

approximately $15 \times$ and $30 \times$ less sensitive than the known sensitive isolates.

On the other hand, the $\mathrm{EC}_{50}$ values for isopyrazam indicated the isolates are still sensitive to that fungicide although isolate 015 had a higher than expected value.

The $E_{50}$ values for epoxiconazole were around $10 \times$ higher in most isolates compared to the reference strains with the exception of isolates 004,026 and 028 where the values are much the same. 026 and 028 both came from adjacent wheat fields managed by the same grower near Masterton.

\section{Pot trials}

Results of the pot trial can be seen in Figure 1. Of the 12 leaves assessed over the 4 replicates, the two untreated and the 007/azoxystrobin treatments at all rates showed a very high level of disease incidence with either 11/12 or $12 / 12$ leaves infected. In contrast, full and $50 \%$ rates of azoxystrobin prevented infection of PF 23C2 entirely.
A lack of effectiveness against isolate 007 was not so marked using epoxiconazole, although even at the full rate, three leaves from the 12 assessed showed lesions with pycnidia. At the $50 \%$ rate, this rose to $8 / 12$ leaves. PF $23 \mathrm{C} 2$ was controlled completely by the full rate of epoxiconazole but $2 / 12$ leaves showed pycnidiabearing lesions with the $25 \%$ rate. The chi-square test for trend showed a significant $(\mathrm{P}<0.01)$ increase in leaves with pycnidia with reducing rates for both fungicide treatments with isolate 007, and for azoxystrobin with isolate PF 23C2.

\section{DISCUSSION}

There is no evidence to suggest any reduced sensitivity to isopyrazam in any of the isolates collected in this study. Even though isolate 015 has a relatively high $\mathrm{EC}_{50}$ compared to the others it is more likely to be due to natural variation in the population than resistance factors, as the SDHI group of fungicides have recently been introduced on the market and have not been used extensively yet in the lower North Island. 


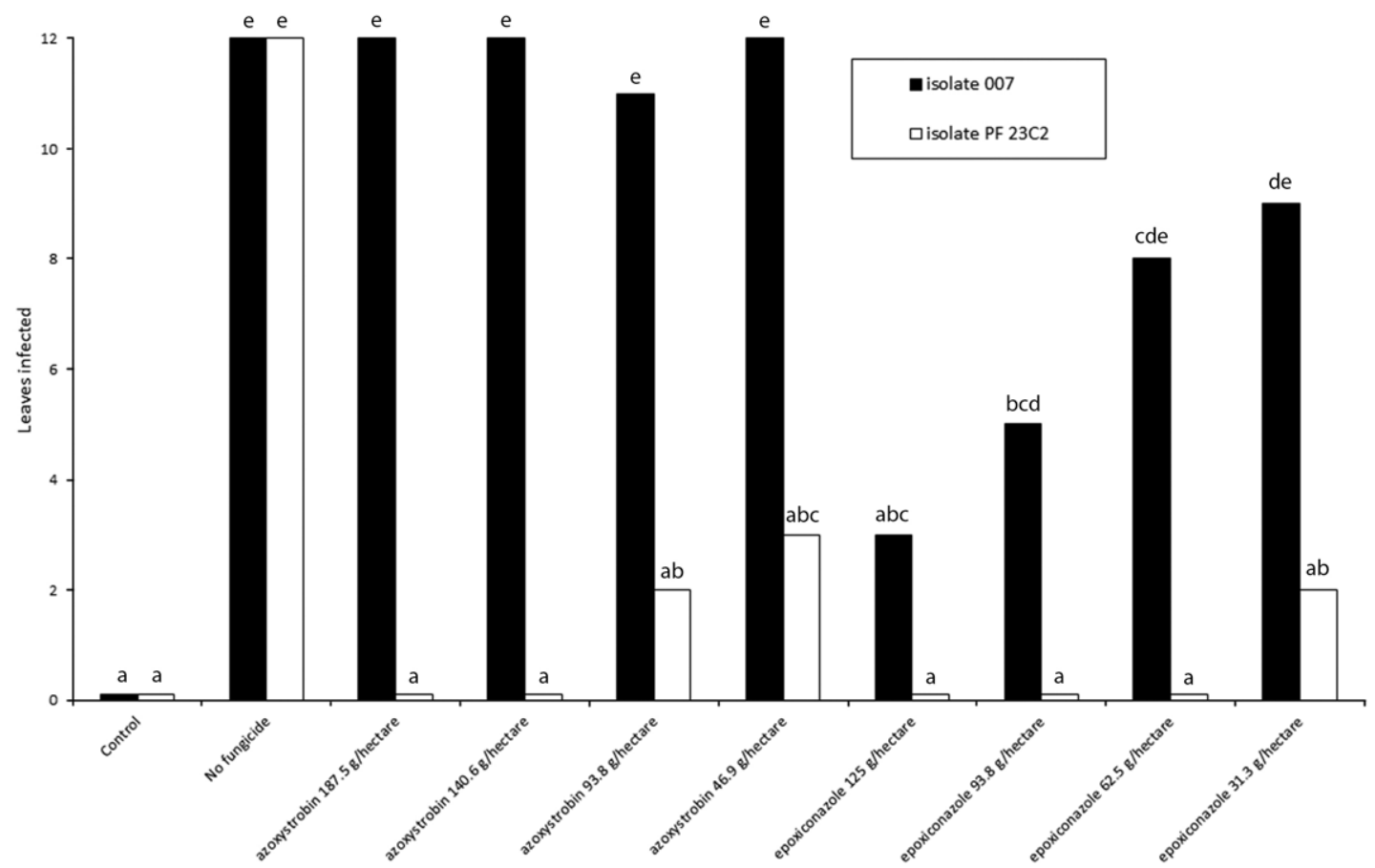

Figure 1 Number of leaves showing pycnidia of $Z$. tritici from a total of 12 leaves (third leaf down from the emerging first leaf on the three largest tillers on four plants) sprayed with varying rates of azoxystrobin and epoxiconazole. Letters indicate which counts are significantly different from one another $(\mathrm{P}<0.05)$ using Fisher's exact test.

For azoxystrobin the situation is very different. Resistance by $Z$. tritici to this fungicide appears widespread in the region. In the pot trial, azoxystrobin applied at the recommended rate showed no ability to prevent infection by a resistant isolate, albeit under extreme infection conditions. Given resistant isolates appear to be common in the lower North Island it is unlikely QoI fungicides alone would be able to control the disease given favourable conditions for the pathogen. This mirrors the situation in Europe, where QoI resistance to $Z$. tritici and B. graminis f. sp. tritici is common (Lucas 2006). Anecdotal evidence suggests speckled leaf blotch has been increasing in the Manawatu/Rangitikei in recent years which may, in part, be a reflection of QoI resistance. The greater inoculum present may have contributed to the 2013 epidemic. It is of concern that QoI resistance to $Z$. tritici is widespread in the region not only in terms of loss of disease control but resistance also negates its role as companion fungicide in mixtures for fungicide resistance management.

Epoxiconazole, the last of the three fungicides tested, was a popular fungicide for the growers covered in the present study. In general, the isolates for epoxiconazole had higher $\mathrm{EC}_{50}$ values when compared with the reference isolates, but the difference between reference and collected isolates was less for epoxiconazole than those for azoxystrobin. However, given the $\mathrm{EC}_{50}$ values of the reference isolates tested against epoxiconazole and the results of the pot trial, the pathogen population appears to be drifting towards epoxiconazole resistance. Stammler \& Semar (2011) found that recommended field rates of epoxiconazole could adequately control $Z$. tritici even when $\mathrm{EC}_{50}$ values approach 
Table $2 \mathrm{EC}_{50}$ values ( $\left.\mathrm{mg} / \mathrm{litre}\right)$ and confidence intervals of collected and reference isolates for three fungicides as calculated from in vitro assays.

\begin{tabular}{|c|c|c|c|c|c|c|}
\hline & \multicolumn{2}{|r|}{ azoxystrobin } & \multicolumn{2}{|c|}{ epoxiconazole } & \multicolumn{2}{|r|}{ isopyrazam } \\
\hline & $\mathrm{EC}_{50}$ & 95\% C.I. & $\mathrm{EC}_{50}$ & 95\% C.I. & $\mathrm{EC}_{50}$ & 95\% C.I. \\
\hline \multicolumn{7}{|c|}{ Sample isolates } \\
\hline 001 & 14.44 & $8.88-23.46$ & 0.41 & $0.28-0.60$ & 0.04 & $0.03-0.05$ \\
\hline 002 & 0.60 & $0.42-0.85$ & 0.33 & $0.22-0.48$ & 0.01 & $0.01-0.02$ \\
\hline 003 & 5.95 & $3.38-10.47$ & 0.72 & $0.52-1.01$ & 0.08 & $0.06-0.10$ \\
\hline 004 & 0.31 & $0.20-0.64$ & 0.06 & $0.04-0.07$ & 0.07 & $0.06-0.08$ \\
\hline 005 & 85.54 & $46.09-158.8$ & 0.18 & $0.11-0.27$ & 0.06 & $0.05-0.08$ \\
\hline 006 & 2.10 & $1.21-3.63$ & 0.21 & $0.15-0.28$ & 0.02 & $0.02-0.03$ \\
\hline 007 & 12.75 & $5.62-28.95$ & 0.96 & $0.70-1.32$ & 0.05 & $0.04-0.06$ \\
\hline 008 & $>100$ & & 0.60 & $0.36-1.00$ & 0.05 & $0.04-0.07$ \\
\hline 009 & 3.16 & $1.74-5.72$ & 0.53 & $0.33-0.87$ & 0.02 & $0.02-0.03$ \\
\hline 010 & 47.15 & $23.22-95.74$ & 0.60 & $0.37-0.98$ & 0.09 & $0.07-0.11$ \\
\hline 011 & 56.18 & $25.19-125.4$ & 0.44 & $0.29-0.65$ & 0.03 & $0.02-0.03$ \\
\hline 012 & 4.10 & $2.15-7.84$ & 0.22 & $0.13-0.38$ & 0.02 & $0.02-0.03$ \\
\hline 014 & 19.46 & $7.74-48.91$ & 0.35 & $0.24-0.53$ & 0.05 & $0.04-0.06$ \\
\hline 015 & 12.58 & $4.91-32.26$ & 0.21 & $0.12-0.37$ & 0.22 & $0.14-0.34$ \\
\hline 016 & 4.30 & $2.34-7.90$ & 0.47 & $0.33-0.68$ & 0.10 & $0.08-0.14$ \\
\hline 017 & 3.67 & $2.06-6.56$ & 0.73 & $0.42-1.26$ & 0.03 & $0.02-0.03$ \\
\hline 022 & 25.84 & $10.89-61.35$ & 0.29 & $0.22-0.39$ & 0.02 & $0.02-0.03$ \\
\hline 023 & 3.47 & $1.93-6.22$ & 0.19 & $0.15-0.24$ & 0.03 & $0.02-0.05$ \\
\hline 025 & 3.77 & $1.95-7.27$ & 0.52 & $0.38-0.71$ & 0.06 & $0.05-0.08$ \\
\hline 026 & 15.22 & $5.01-46.24$ & 0.07 & $0.05-0.09$ & 0.08 & $0.06-0.11$ \\
\hline 027 & 32.59 & $9.81-108.4$ & 0.76 & $0.47-1.20$ & 0.03 & $0.03-0.04$ \\
\hline 028 & 12.00 & $7.25-19.87$ & 0.03 & $0.02-0.05$ & 0.03 & $0.02-0.04$ \\
\hline 029 & 15.66 & $7.47-32.83$ & 0.54 & $0.36-0.81$ & 0.04 & $0.04-0.05$ \\
\hline \multicolumn{7}{|c|}{ Reference Isolates } \\
\hline PF 23C2 & 0.02 & $0.01-0.05$ & 0.04 & $0.03-0.05$ & 0.05 & $0.04-0.06$ \\
\hline PF 23C3 & 0.02 & $0.01-0.03$ & 0.04 & $0.03-0.06$ & 0.03 & $0.03-0.04$ \\
\hline PF 23C4 & 0.02 & $0.01-0.04$ & 0.04 & $0.03-0.05$ & 0.04 & $0.04-0.05$ \\
\hline
\end{tabular}

$1.0 \mathrm{mg} /$ litre. The pot trial showed some infection at full rates of epoxiconazole with an isolate with an $\mathrm{EC}_{50}$ of approximately $0.96 \mathrm{mg} /$ litre. However, the pot trial does not reflect the field situation fully. Plants and fungicides were challenged with a high inoculum load and ideal infection conditions. Nevertheless this result adds weight to the evidence that resistance to epoxiconazole as measured in the laboratory may translate to infection in the field given a susceptible host and the right environmental conditions.

This research was carried out to determine if fungicide resistance was the primary cause of speckled leaf blotch outbreaks in Manawatu/ Rangitikei in the spring of 2013. Certainly, resistance to QoI fungicides and loss of sensitivity to epoxiconazole appears to be present in the pathogen population. This may have had a role to play but it is unlikely to be the only cause. Another factor could have been the weather. In September of 2013, much of the region surveyed had more than $150 \%$ of normal rainfall (NIWA 2013). Crops are likely to have remained wet for over $72 \mathrm{~h}$, which is more than enough for successful infections (Eyal et al. 1987). The rate at which the fungicides were applied may also have contributed. Information collected during the study showed that growers were commonly using lower than the recommended label rates of fungicide. Furthermore it appears to have been a widespread practice for a number of years. Van Toor et al. (2013) found applying lower than recommended rates of cereal fungicides was a common practice in cereal crops in their 
2008-2009 survey, with only one-third of DMI fungicides applied at the full rate. Surveyed growers were commonly using epoxiconazole rates between 30 to $60 \%$ of the label rate.

The participating growers were all clients of one large merchant firm but anecdotal evidence would suggest the use of low rates is common across the sector, at least in the region under study. The widespread usage of these low rates has come about from industry trials, which show that rates could seemingly be safely lowered while diseases in general were held at bay given good spray timing and the appropriate cultivars (Foundation for Arable Research 2012). In doing so the cost of production is reduced. However, most trials were conducted in Canterbury where speckled leaf blotch has been regarded as less of a problem in autumn-sown crops when compared to the UK and Northern Europe (Foundation for Arable Research 2009). Rust diseases are more likely to be the target of the early sprays at GS30-GS32.

Historically speckled leaf blotch has been less significant in the Manawatu/Rangitikei area than Canterbury. In contrast to North/Mid-Canterbury and Southland, a 1995-1996 survey by Braithwaite et al. (1998) found no incidence of the disease in the Wanganui and Wellington regions in the 16 sites surveyed. At that time virtually the entire wheat crop in those regions is likely to have been spring sown. This is not the case at present. In the past 10 years there has been a move towards autumnsown wheat crops in the lower North Island. This has meant there is less industry experience or local knowledge of potential diseases for autumnsown wheat than in areas where autumn sowing is common. Furthermore, the prevalence and importance of diseases in Manawatu/Rangitikei wheat crops are likely to differ from Canterbury. The cool, wet conditions typifying spring on the western side of the southern North Island are conducive for $Z$. tritici infection of autumn-sown crops. Given higher disease pressure is more likely in the lower North Island than in Canterbury, where most disease control trials have been carried out, the use of reduced fungicide rates in the former region may not be tenable.
It should be pointed out that the Foundation for Arable Research (FAR) states that "Use of rates lower than the full label rate is done at the grower's own risk.". It also recommends prothioconazole be used in place of epoxiconazole for early sprays where speckled leaf blotch is likely to be a threat (Foundation for Arable Research 2012). However, most of the affected growers in the present study used epoxiconazole as an early spray. While epoxiconazole suppresses $Z$. tritici growth it is less effective than some other fungicides. For example, both Marroni et al. (2006) and Godwin et al. (1994) found epoxiconazole did not inhibit the early stages of a $Z$. tritici infection as much as azoxystrobin (assuming a sensitive strain of the pathogen).

It is important to note that low fungicide rates are not being suggested as the cause of azoxystrobin or epoxiconazole resistance in this study. Indeed, recent research suggests low rates of high-risk fungicides do not accelerate resistance development (van den Bosch et al. 2011; Hobbelen et al. 2014). The problem with low rates is that they can fail to check disease where environmental conditions are conducive for infection and spread of pathogens, especially those with reduced sensitivity to the fungicide.

In conclusion, both azoxystrobin and epoxiconazole resistance may have been a factor in the high levels of speckled leaf blotch in the lower North Island in the spring of 2013 but environmental conditions and a lack of experience with, and knowledge of the significance of, the disease in autumn-sown crops in the region (resulting in low fungicide rates and less than ideal fungicide selection) is also likely to have played a part.

\section{ACKNOWLEDGEMENTS}

The authors would like to thank Suvi ViljanenRollinson of Plant \& Food Research for the reference isolates and advice on the assays, Syngenta for supplying GLP-grade Amistar (azoxystrobin), BASF New Zealand for contacts in BASF Germany regarding assay details and Eric Altermann of AgResearch for assistance with assay design. 


\section{REFERENCES}

Anonymous 2013. New Zealand Novachem Agrichemical Manual. AgriMedia Limited, Wellington, New Zealand. 768 p.

Braithwaite M, Alexander BJR, Adams RLM 1998. Nationwide survey of pests and diseases of cereal and grass seed crops in New Zealand. 2. Fungi and Bacteria. Proceedings of the 51st New Zealand Plant Protection Conference: 51-59

Cools HJ 2008. Are azole fungicides losing ground against Septoria wheat disease? Resistance mechanisms in Mycosphaerella graminicola. Pest Management Science 64: 681-684.

Cools HJ, Fraaje BA, Lucas JA 2005. Molecular mechanisms correlated with changes in triazole sensitivity in isolates of Mycosphaerella graminicola. Proceedings of the BCPC International Congress, Crop Science \& Technology: 267-274

Cools HJ, Mullins JGL, Fraaije BA, Parker JE, Kelly DE, Lucas JA, Kelly SL 2011. Impact of recently emerged sterol 14 -demethylase (CYP51) variants of Mycosphaerella graminicola on azole fungicide sensitivity. Applied Environmental Microbiology 77: 3830-3837.

Cools HJ, Fraaije BA 2013. Update on mechanisms of azole resistance in Mycosphaerella graminicola and implications for future control. Pest Management Science 69: 150-155.

Eyal Z, Scharen AL, Prescott JM, Van Ginkel M 1987. The Septoria diseases of wheat: Concepts and methods of disease management. CIMMYT, Mexico. ISBN 9686127-06-2.

Eyal Z 1999. The Septoria tritici and Stagonospora nodorum blotch diseases of wheat. European Journal of Plant Pathology 105: 629-641

Foundation for Arable Research 2009. Cereal Growth Stages. The link to disease management. Foundation for Arable Research booklet. Issue 2 - Spring. ISBN 9780-9864533-1-1.p. 27
Foundation for Arable Research 2012. Cropping Strategies. A summary of recent research findings. Foundation for Arable Research booklet. Issue 3 - Spring. ISSN 23241381. http://www.far.org.nz/mm_uploads/ FAR_strategy_issue_3_cereal_fungicide.pdf (accessed 15 May 2014). Pp. 10-11.

Foundation for Arable Research 2013. Crop Action 59 (6 December) http://www.far.org. nz/mm_uploads/131206_Crop_Action_1. pdf (accessed 15 May 2014). Pp. 6-7.

Fraaije BA, Burnett FJ, Clark WS, Motteram J, Lucas JA 2005. Resistance development to QoI inhibitors in populations of Mycosphaerella graminicola in the UK. In: Modern Fungicides and Antifungal Compounds IV. BCPC, Alton, UK. Pp. 63-72.

Godwin JR, Young JE, Hart CA 1994. ICIA5504: effects on development of cereal pathogens. Brighton Crop Protection Conference - Pests and Diseases. Pp. 259-264.

Hobbelen P, Paveley N, van den Bosch F 2014. The emergence of resistance to fungicides. PLoS ONE DOI:10.1371/journal. pone.0091910. http://www.plosone.org/ article/info\%3Adoi\%2F10.1371\%2Fjournal. pone.0091910 (accessed 16 June 2014).

Jørgensen LN, Hovmøller MS, Hansen JG, Lassen P, Clark B, Bayles R, Rodemann B, Flath K, Jahn M, Goral T, Czembor JJ, Cheyron P, Maumene C, De Pope C, Ban R, Nielsen GC, Berg G 2014. IPM Strategies and their dilemmas including an introduction to www.eurowheat.org. Journal of Integrative Agriculture 13: 265-281.

Lucas J 2006. Resistance to QoI fungicides: implications for cereal disease management in Europe. Pesticide Outlook 14: 268-271.

Marroni MV, Viljanen-Rollinson RC, Butler RC, Deng Y 2006. Fungicide timing for the control of Septoria tritici blotch of wheat. New Zealand Plant Protection 59: 160-165.

NIWA 2013. National Climate Summary: September 2013. https://www.niwa.co.nz/sites/niwa.co.nz/ files/climate_summary_september_2013_ final_0.pdf (accessed 16 June 2014). 
Quaedvlieg W, Kema GH J, Groenewald JZ, Verkley GJM, Seifbarghi S, Razavi M, Gohari AM, Mehrabi R, Crous PW 2011. Zymoseptoria gen. nov.: A new genus to accommodate Septoria-like species occurring on graminicolous hosts. Persoonia 26: 57-69.

Shaw MW, Royle DJ 1993. Factors determining the severity of epidemics of Mycosphaerella graminicola (Septoria tritici) on winter wheat in the UK. Plant Pathology 42: 882899.

Siah A, Deweer C, Morand E, Reignault Ph, Halama P 2010. Azoxystrobin resistance of French Mycosphaerella graminicola strains assessed by four in vitro bioassays and by screening of G143A substitution. Crop Protection 29: 737-743.

Skinner W, Bailey A, Renwick A, Keon J, Gurr S, Hargreaves J 1998. A single amino-acid substitution in the iron-sulphur protein subunit of succinate dehydrogenase determines resistance to carboxin in Mycosphaerella graminicola. Current Genetics 34: 393-398.

Stammler G, Semar M 2011. Sensitivity of Mycosphaerella graminicola (anamorph: Septoria tritici) to DMI fungicides across Europe and impact on field performance. OEPP/EPPO Bulletin 41: 149-155.
Statistics New Zealand 2012. Grain and Seed Crops by Region (Year to 30th June). http:// www.stats.govt.nz/browse_for_stats/ industry_sectors/agriculture-horticultureforestry/2012-agricultural-census-tables/ grain-and-arable.aspx (accessed 15 May 2014).

Sierotzki H, Scalliet G 2013. A review of current knowledge of resistance aspects for the nextgeneration succinate dehydrogenase inhibitor fungicides. Phytopathology 103: 880-887.

Torriani SFF, Brunner PC, McDonald BA, Sierotzki H 2009. QoI resistance emerged independently at least 4 times in European populations of Mycosphaerella graminicola. Pest Management Science 65: 155-162.

van den Bosch F, Paveley N, Shaw M, Hobbelen P, Oliver R 2011. The dose rate debate: does the risk of fungicide resistance increase or decrease with dose? Plant Pathology 60: 597-606.

van Toor RF, Viljanen-Rollinson SLH, Rahman A, Teulon DAJ 2013. Agrichemical use on wheat and barley crops in New Zealand in 2008-09. New Zealand Journal of Crop and Horticultural Science 41: 9-22.

Wood PM, Hollomon DW 2003. A critical evaluation of the role of alternative oxidase in the performance of strobilurin and related fungicides acting at the Qo site of Complex III. Pest Management Science 59: 499-511.

Ziogas BN, Baldwin BC, Young JE 1997. Alternative respiration: a biochemical mechanism of resistance to azoxystrobin (ICIA 5504) in Septoria tritici. Pesticide Science 50: 28-34. 